ISSN: 2224-0616

Int. J . Agril. Res. Innov. \& Tech. 4 (2): 82-86, December, 2014 Available online at http://www.ijarit.webs.com

\title{
PERFORMANCE EVALUATION OF LASER GUIDED LEVELER
}

\author{
M.A. Hoque ${ }^{* *}$ and M.A. Hannan²
}

Received 31 October 2014, Revised 23 November 2014, Accepted 22 December 2014, Published online 31 December 2014

\begin{abstract}
The study was conducted at Bangladesh Agricultural Research Institute (BARI) farm on clay loam soil during Rabi season of 2010-2011. The treatments consisted of laser land leveling $\left(\mathrm{T}_{1}\right)$ and control (non-leveled) $\left(\mathrm{T}_{2}\right)$. A preliminary field survey was done using staff gage. Initially a base station was established to dispense laser ray uniformly. The laser ray erected from base station guided the sensor of the stuff gage and the leveler. Elevation data was collected from the different points of the field and made an average. The maximum gage reading were $247.0 \mathrm{~cm}$ and the minimum gage reading was $219.2 \mathrm{~cm}$. Average gage readings of the laser leveled plot was $235.66 \mathrm{~cm}$ that was settled for auto adjustment. Therefore, huge amount of soils ( $16.46 \mathrm{~cm}$ high) was cut from the highest point and subsequently had to fill to the low points. Finally, an equal gage reading of $235.66 \mathrm{~cm}$ was observed after leveling the plot. The laser leveler (Leica MLS700) was used hitching with a TAFE tractor. The field was leveled with manual control initially and finally it was operated with auto adjustment. Two operators, 25 litter diesels and total 6 hours time were required during this leveling. Wheat was cultivated in leveled land $\left(T_{1}\right)$ and non-leveled land $\left(T_{2}\right)$. Laser leveling was insured for improvement in nutrient use efficiencies, option for precision farming, reduces weed problems, and improves uniformity of crop maturity. There was better distribution of water in leveled plot, which helped to reduce irrigation application time 1 hour. Due to uniformity of moisture content improved germination and crop establishment was found which reflected in higher plant population $\left(239 \mathrm{~m}^{-2}\right)$. Maximum yield $\left(3.41 \mathrm{t} \mathrm{ha}^{-1}\right)$ was obtained in $\mathrm{T}_{1}$ due to longer panicle $(10.89 \mathrm{~cm})$, more grain per plant (27.47) and 1000 grain weight (47.38 g) compared to yield of $\mathrm{T}_{2}$ (2.62 tha-1).
\end{abstract}

Keywords: Performance, Laser Guided Leveler, Bangladesh

${ }^{1}$ Senior Scientific Officer, F M P Engineering Division, Bangladesh Agricultural Research Institute, Gazipur-1701, Bangladesh

${ }^{2}$ Senior Scientific Officer, Seed Technology Division, Bangladesh Agricultural Research Institute, Gazipur-1701, Bangladesh

*Corresponding author's email: arshadulfmpe@gmail.com, arshadul@bari.gov.bd (M.A. Hoque)

\section{Introduction}

The land leveling provides smoother soil surface, reduction in time and water required to irrigate the field, more uniform distribution of water in the field, more uniform moisture environment for crops, more uniform germination and growth of crops, reduction in seed weight, fertilizer, chemicals and fuel used in cultivation, and improved field traffic ability (for subsequent operations). Limitations of laser leveling include high cost of the equipment/laser instrument, the need for a skilled operator to set/adjust laser settings and operate the tractor, and restriction to regularly shaped fields. Usually laser leveling is done for better distribution of water, water savings, improvement in nutrient use efficiencies, option for precision farming, higher crop productivity, saves $25-30 \%$ of water, improves crop establishment and improves yield, reduces weed problems, improves uniformity of crop maturity, decreases the time to complete tasks, reduces the amount of water required for land preparation.
In 1980s, leveling of surface of the irrigated blocks became major practice in Soviet Central Asian states. The land leveling was applied as water saving method and have shown promising results, water use have been reduced by $1,500 \mathrm{~m}^{3}$ ha $^{-1}$ in leveled fields (Ahmedjanov, 1984; Ahmedjanov et al., 1988; Balabanov, 1984). Review of existing literature on land leveling indicated positive impact on water saving, crop and farm productivity (J onish, 1991; Clemmens et al., 1995; Ren et al., 2003; Mallappa and Radder, 1993; Cheema and Zulfiqar, 1998). It it is applied effectively, and leveling increases crop germination and yields and improves water distribution (Rickman, 2002).

The use of laser technology in the precision land leveling not only minimizes the cost of leveling but also ensures the desired degree of precision. Precision land leveling has been a significant component of on farm water management since 1977. Land leveling of farmer's field is an 
important process in the preparation of land. It enables efficient utilization of scarce water resources through elimination of unnecessary depressions and elevated contours (Muhammad Asif et al., 2003). It has been noted that poor farm design and uneven fields are responsible for $30 \%$ water losses. About 18 million-acre feet (MAF) of water is lost to irrigate uneven fields in Pakistan (Gill, 1998). Salinity patches in the elevated parts and leaching down of soil nutrients from the root zone in lower spots of unleveled fields can attribute towards low crop production (Muhammad Asif et al., 2003). Precision land leveling (PLL) facilitated application efficiency through even distribution of water and increased water-use efficiency that resulted in uniform seed germination, better crop growth and higher crop yield (Nazir, 1994). The scarcity of canal water supplies coupled with unfit underground water has compelled the farmers to utilize available water resources more wisely and efficiently. Under these circumstances, PLL can help the farmers to utilize the scarce land and water resource more effectively and efficiently towards increased crop production.

Conventional land leveling includes surveying of the field, staking and designing the field, calculation of cut and fills areas and then use of a scraper and land planer. Despite all these laborintensive efforts, desired accuracy is not achieved. By contrast, laser leveling involves the use of a laser (transmitter), that emits a rapidly rotating beam parallel to the required field plane, which is picked up by a senor (receiving unit) fitted to a tractor towards scraper unit. The signal received is converted into cut and fill level adjustment and the corresponding changes in scraper level are carried out automatically by a hydraulic control system. The scraper guidance is fully automatic; the elements of operator error are removed allowing consistently accurate land leveling. The laser leveling makes the flow uniform and the advance flow is not much hindered because of less irregularity in the field's micro-topography. In a word, the laser controlled land leveling facilitates advance phase and consequently more uniformity is achieved.

Laser technology can ensure very accurate and precision land leveling to the extent of $\pm 2 \mathrm{~cm}$ (Waker, 1989). However, necessary data to support its effects on crop yield and water use are scarce. It was therefore, felt imperative to evaluate the performance of the laser guided leveler and its impact on yield of wheat.

\section{Materials and Methods}

The study was conducted at block no 6 of Bangladesh Agricultural Research Institute (BARI) field on clay loam soil during Rabi season of 2010-2011. The treatments consisted of Laser land leveling $\left(\mathrm{T}_{1}\right)$ and Control (Non-leveled) $\left(\mathrm{T}_{2}\right)$. In treatments $T_{1}$ and $T_{2}$, leveling of experimental field was done as per treatment and information on the topography of each experimental unit was compiled. The net plot size of each treatment measured was $60 \times 22 \mathrm{~m}^{2}$. A preliminary field survey was done using staff gage. Initially a base station was established to dispense laser ray uniformly as shown in Fig 1. It was a battery operated device, which covers a command area with $500 \mathrm{~m}$ radius. The laser ray erected from base station guides the sensor of the stuff gage and the leveler (Fig. 2). Elevation data was collected from the different points of the field as located in Fig. 3. From the elevation data, an average elevation was fixed for the leveler to operate automatically.

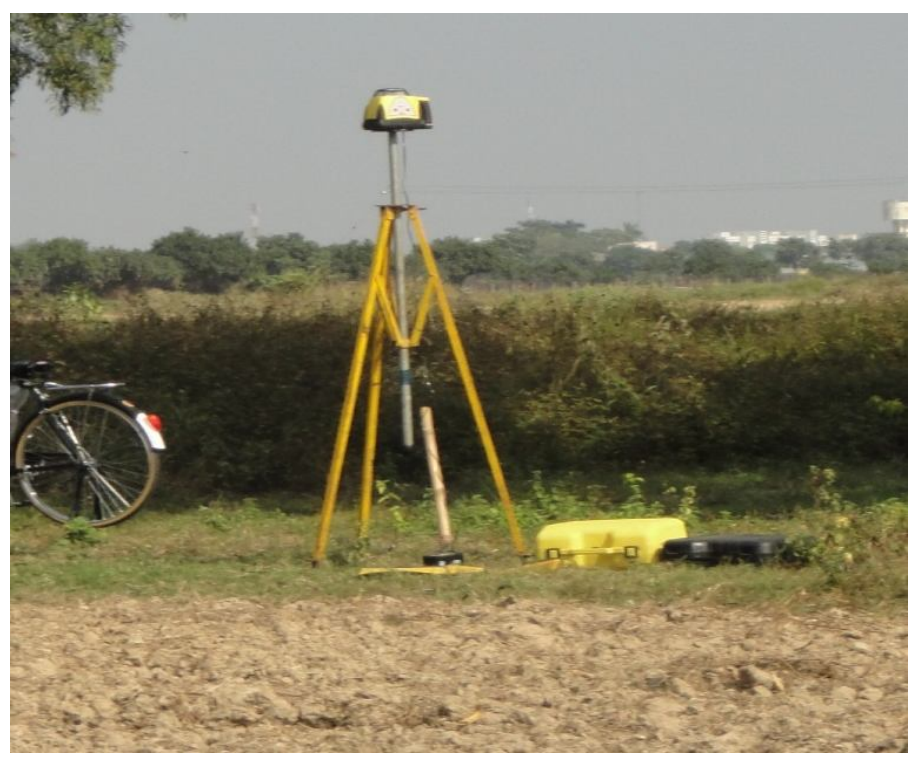

Fig. 1. Laser base station 


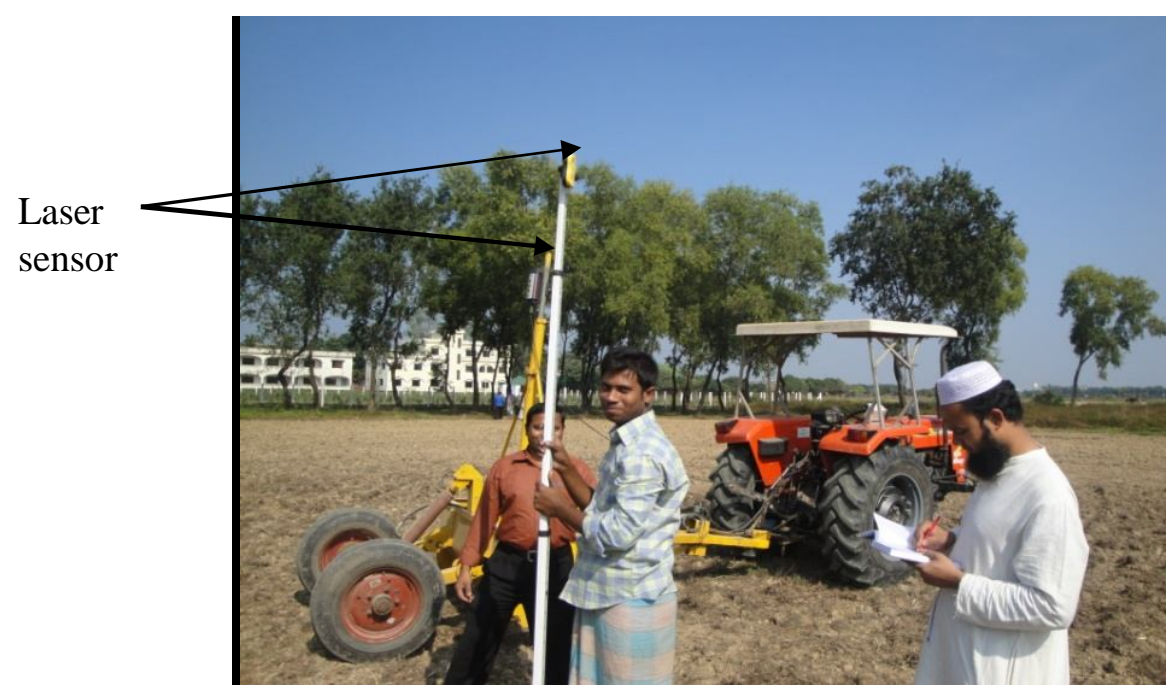

Fig. 2. Sensors in stuff gage and the leveler

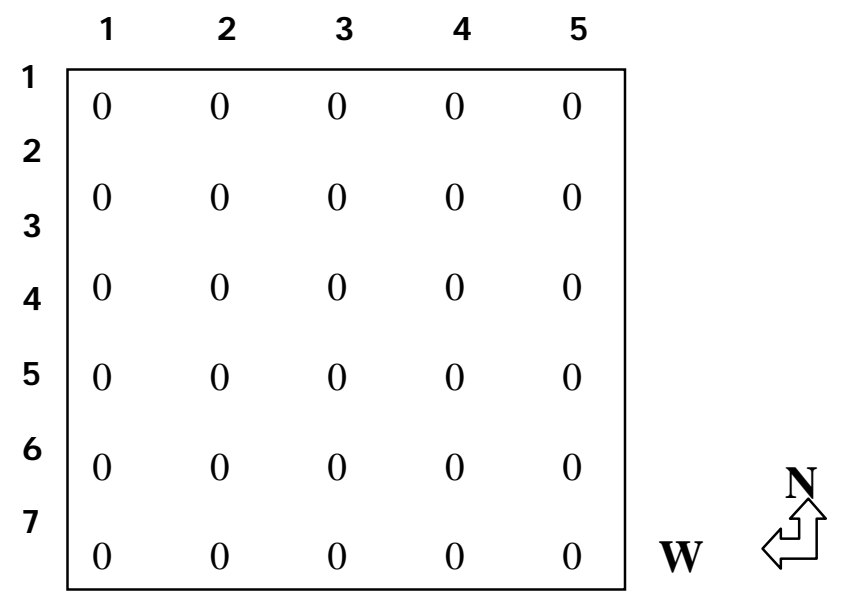

Fig. 3. Layout of elevation data collection points

The main source of irrigation was canal water, which was supplemented with tube well water as and when needed to meet the crop water requirements.

Wheat variety Bijoy was sown on December 22 by BARI Inclined plate seeder. A basal dose of NPK in the form of Urea and TSP @ 123-98-0 kg ha- ${ }^{1}$ were applied. Three irrigations were given till the maturity of the crop. The crop was kept free from weeds. Observations on the desired parameters were reconded using the standard procedures. The discharge available at outlet was measured every time. The time of irrigation application for each treatment was noted.

\section{Results and Discussion}

Laser leveler was used to level the field. Preliminary contour surveys were done and make an average to level. Fig. 4 shows the contour map and laser leveled line of the field from west to east respectively. Maximum gage reading indicate the lowest point of the field and minimum gage reading indicate the highest point of the field. From Fig. 4, it was observed that the maximum gage reading was $247 \mathrm{~cm}$ and the minimum gage reading was $219.2 \mathrm{~cm}$. If whole plot would be leveled then the average gage reading should be $233.41 \mathrm{~cm}$ to set for auto adjustment. However, average gage reading of the laser leveled plot was $235.66 \mathrm{~cm}$ that was settled for auto adjustment. Therefore, huge amount soils (16.46 cm high) were cut from the highest point and subsequently have to fill to the low points. Finally, an equal gage reading of $235.66 \mathrm{~cm}$ was observed after leveling the plot. 


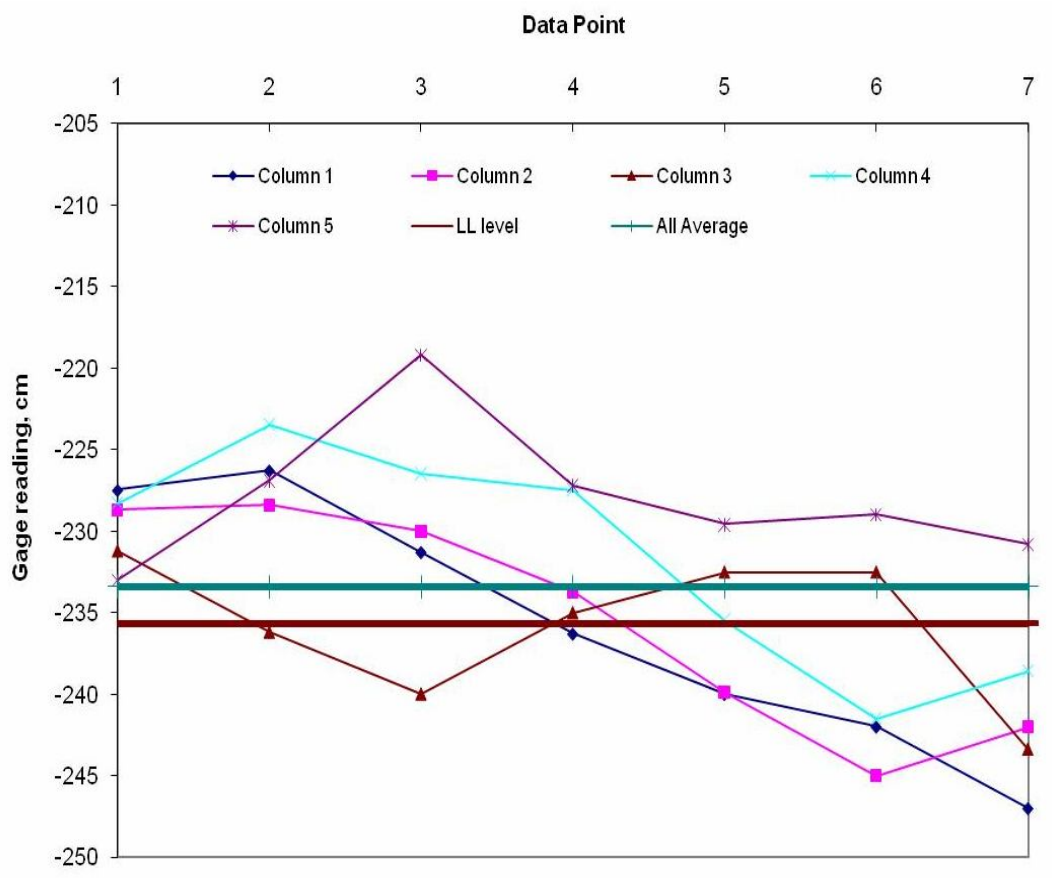

Fig. 4. The contour map and laser leveled line of the field.

The laser leveler was used hitching with a TAFE 2 operators, 25 litter diesels and total 6 hours tractor. The field was leveled with manual control time. However, for others it will vary for the initially and finally it was operated with auto variation in land topography.

adjustment. Some operational parameters have shown in Table 1. For this experiment, it required

Table 1. Operational parameters of the test used in the experiment

\begin{tabular}{lc}
\hline Parameters & Values \\
\hline Plot size $\left(\mathrm{m}^{2}\right)$ & 1320 \\
Time required for adjustment $(\mathrm{hr})$ & 1 \\
Time required for leveling $(\mathrm{hr})$ & 5 \\
Fuel consumption $(\mathrm{l} \mathrm{hr}-1)$ & 5 \\
No. of operators $($ no.) & 2 \\
Brand of the tractor & TAFE \\
Brand of the laser leveler & Leica MLS700 \\
Length of the cutting unit $(\mathrm{cm})$ & 172 \\
Forward speed $\left(\mathrm{km} \mathrm{hr}^{-1}\right)$ & 3.1 \\
\hline
\end{tabular}

Laser leveling was insured improvement in nutrient use efficiencies, option for precision farming, reduces weed problems, improves uniformity of crop maturity, and decreased the time to complete tasks. Yield parameters and irrigating time are shown in Table 2 . In treatment $\mathrm{T}_{1}$, there was better distribution of water, which helps to reduce 1 hour irrigation application time.
Due to uniformity of moisture content improved germination and crop establishment was found which reflected in higher plant population (239 $\left.\mathrm{m}^{-2}\right)$. Longer panicle $(10.89 \mathrm{~cm})$, more grain per plant (27.47) and 1000-grain weight (47.38 g) insured maximum yield $\left(3.41 \mathrm{t} \mathrm{ha}^{1}\right)$ in $\mathrm{T}_{1}$ whereas in $\mathrm{T}_{2}$ yield was 2.62 t ha- $^{-1}$.

Table 2. Yield parameters and irrigating time

\begin{tabular}{cccccccc}
\hline $\begin{array}{l}\text { Treat } \\
\text { ments }\end{array}$ & $\begin{array}{c}\text { Plant } \\
\text { height } \\
(\mathrm{cm})\end{array}$ & $\begin{array}{c}\text { Plant } \\
\text { Population } \\
\mathrm{m}^{-2}\end{array}$ & $\begin{array}{c}\text { Length of } \\
\text { panicle } \\
(\mathrm{cm})\end{array}$ & $\begin{array}{c}\text { No. of grain/ } \\
\text { Panicle }\end{array}$ & $\begin{array}{c}1000 \\
\text { grain wt } \\
(\mathrm{g})\end{array}$ & $\begin{array}{c}\text { Yield } \\
\left(\text { t ha }^{-1}\right)\end{array}$ & $\begin{array}{c}\text { Irrigation } \\
\text { time }(\mathrm{hr})\end{array}$ \\
\hline $\mathrm{T}_{1}$ & 74.5 & 239 & 10.89 & 27.47 & 47.38 & 3.41 & 7 \\
$\mathrm{~T}_{2}$ & 65.87 & 208.2 & 9.93 & 25.93 & 46.73 & 2.62 & 8 \\
\hline
\end{tabular}




\section{Conclusion}

The maximum gage reading was $247 \mathrm{~cm}$ and the minimum gage reading was $219.2 \mathrm{~cm}$. Average gages reading of the laser leveled plot was 235.66 $\mathrm{cm}$ that was settled for auto adjustment. So, a huge amount soil (16.46 cm high) was cut from the highest point and subsequently was to fill to the low points. Finally, an equal gage reading of $235.66 \mathrm{~cm}$ was observed after leveling the plot. Laser leveling was insured improvement in nutrient use efficiencies, option for precision farming, reduces weed problems, improves uniformity of crop maturity, and decreases the time to complete tasks. There was better distribution of water in leveled plot, which helps to reduce 1 hour irrigation application time. Due to uniformity of moisture content improved germination and crop establishment was found which reflected in higher plant population (239 $\left.\mathrm{m}^{-2}\right)$. Longer panicle $(10.89 \mathrm{~cm})$, more grain per plant (27.47) and 1000 grain weight (47.38 g) insured maximum yield ( 3.41 t ha- $\left.^{-1}\right)$ in $\mathrm{T}_{1}$ whereas in $\mathrm{T}_{2}$ yield was $2.62 \mathrm{t} \mathrm{ha}^{-1}$.

\section{References}

Ahmedjanov, M. 1984. Application and investigation of the laser leveling in the field level. Fan, Tashkent, p. 144 (in Russian).

Ahmedjanov, M., Manabaev, A.N.T. and Teshabaev, A.Z 1988. Application of laser for land leveling. J. Mechanized Cotton Prod. 12: 4-6 (in Russian).

Balabanov, S.V. 1984. The application of laser equipment for land leveling in the irrigated agriculture. Geodesy and photogram in the ameliorative construction. Novocherkassk. pp. 54- 68 (in Russian).

Cheema, S. and Zulfiqar, M. 1998. The impact of laser land leveling on crop production in district Faisalabad. Pakistan J. WM. 1: 1326.
Clemmens, A.J., Dedrick, A.R., Pereira, L.S., Sousa, P.L. and Pereira, L.S. 1995. Effect of furrow elevation differences on level-basin performance. J. American Soc. Agric. Eng. 38 (1): 153-158.

Gill, M. 1998. Water for life. Proceeding of seminar on world food day. Directorate of Agriculture Information. Dept. Agric. Govt. Punjab, India. pp. 9-13.

J onish, J.E. 1991. Benefits and costs of laser land leveling Egypt. In: Bishay A, Dregne H (eds) Desert development Part 1: desert agriculture, ecology and biology: Proceedings of the Second International Desert Development Conference held on 2531 J anuary 1987 in Cairo, Egypt. vol. 4. pp. 6-9.

Mallappa, M., Radder, G.D. 1993. Evaluation of different proportion of leveling in Zingg conservation terraces on soil moisture conservation, crop growth and yield of green gram. Mysore J. Agric. Sci. 6 (3): 241-246.

Muhammad Asif, Manzoor Ahmed, Abdul Gafoor and Zhahoor Aslam. 2003. Wheat productivity, land and water use efficiency by traditional and laser land - leveling techniques. Online J. Biol. Sci. 3 (2): 141146.

Nazir, M.S. 1994. Crop production. Crop water requirement and irrigation system. National Book Foundation. pp. 63-67.

Ren, W.T., Hu, Z.F., Cui, H.G., Yang, C.T., Liu, Y., Wang, Y.J., Zhang, Z.Y.and Li, B.F. 2003. Effect of laser-controlled land leveling and baby rice seedling direct planting on saving water. Trans. China Soc. Agric. Eng. 19 (3): 72-75.

Rickman, J. 2002. Land leveling. International Rice Research Institute. Philipine. p. 29.

Waker, W.R. 1989. Guidelines for design and evaluation surface irrigation system. FAO, Irigation and Drainage Paper no. 45 FAO, Rome, Italy. 